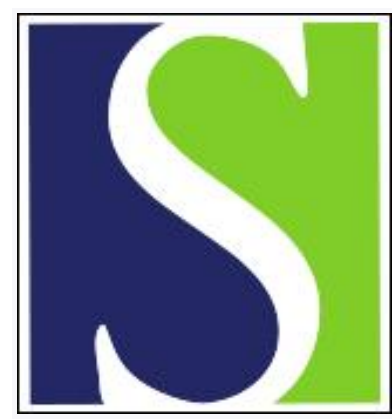

Scand J Work Environ Health 2010;36(2):134-141

https://doi.org/10.5271/sjweh.2890

Published online: 29 Dec 2009, Issue date: 00 Mar 2010

Night work and breast cancer - results from the German GENICA study

by Pesch B, Harth V, Rabstein S, Baisch C, Schiffermann M, Pallapies D, Bonberg N, Heinze E, Spickenheuer A, Justenhoven C, Brauch $\mathrm{H}$, Hamann U, Ko Y, Straif K, Brüning T

Affiliation: Research Institute of Occupational Medicine of the German Social Accident Insurance (BGFA), 44789 Bochum, Germany. pesch@bgfa.de

Refers to the following text of the Journal: 2008;34(1):5-22

The following articles refer to this text: 2010;36(2):163-179; 2010;36(2):81-84; 2012;38(6):590-599; 2012;38(6):553-559; 2013;39(2):170-177; 2013;39(5):448-455; 2013;39(5):431-447; 2014;40(3):295-304; 2014;40(5):502-510; 2017;43(1):59-67

Key terms: breast cancer; cancer; case-control study; GENICA study; Germany; health; health; night work; occupation; shift work

This article in PubMed: www.ncbi.nlm.nih.gov/pubmed/20039012 


\title{
Night work and breast cancer - results from the German GENICA study
}

\author{
by Beate Pesch, PhD, ${ }^{1,2}$ Volker Harth, MD, MPH, ${ }^{1,2}$ Sylvia Rabstein, MSc, ${ }^{2}$ Christian Baisch, MA, ${ }^{3}$ Markus \\ Schiffermann, MA, ${ }^{3}$ Dirk Pallapies, MD, ${ }^{2}$ Nadine Bonberg, ${ }^{2}$ Evelyn Heinze, ${ }^{2}$ Anne Spickenheuer, MSc, ${ }^{2}$ \\ Christina Justenhoven, PhD, ${ }_{4}^{4}$ Hiltrud Brauch, PhD, ${ }^{4}$ Ute Hamann, PhD, ${ }^{5}$ Yon Ko, MD, ${ }^{3}$ Kurt Straif, MD, ${ }^{6}$ \\ Thomas Brüning, $M D^{2}$
}

\begin{abstract}
Pesch B, Harth V, Rabstein S, Baisch C, Schiffermann M, Pallapies D, Bonberg N, Heinze E, Spickenheuer A, Justenhoven C, Brauch H, Hamann U, Ko Y, Straif K, Brüning T. Night work and breast cancer - results from the German GENICA study. Scand J Work Environ Health. 2010;36(2):134-141.
\end{abstract}

\begin{abstract}
Objective Some epidemiological and animal data indicate that night work might increase the risk for breast cancer. We have investigated the risk in a German population-based case-control study known as GENICA (Gene ENvironment Interaction and breast CAncer).

Methods The GENICA study involved interviews to assess shift work information in 857 breast cancer cases and 892 controls. We estimated risks of employment status and night shift characteristics using conditional logistic regression models, adjusting for potential confounders. Resampling and bootstrapping were applied to adjust the risk estimates for a potential selection bias.
\end{abstract}

Results Among 1749 women, 56 cases and 57 controls worked in night shifts for $\geq 1$ year, usually in the healthcare sector $(63.0 \%$ of controls). Female night workers were more frequently nulliparous and low-educated than day workers ( $28.6 \%$ versus $17.8 \%$ and $12.3 \%$ versus $9.2 \%$, respectively). Fewer women in night work had ever used post-menopausal hormone therapy (35.7\% versus $51.9 \%)$. Having ever done shift or night work was not associated with an elevated breast cancer risk when compared to women employed in day work only [odds ratio (OR) $0.96,95 \%$ confidence interval $(95 \% \mathrm{CI}) 0.67-1.38$ and OR $0.91,95 \%$ CI $0.55-1.49$, respectively). Women who reported $>807$ night shifts, the third quartile of the distribution among controls, experienced a breast cancer risk of 1.73 (95\% CI 0.71-4.22). Night work for $\geq 20$ years was associated with an OR of 2.48 (95\% CI $0.62-9.99$ ) based on 12 cases and 5 controls.

Conclusions Long-term night work was associated with a modestly, but not significantly, increased breast cancer risk, while having ever done night work was not. The precision of the results was limited by a low prevalence of night work in this study population.

Key terms case-control study; occupation; shift work.

Night work is inevitable for important tasks in the healthcare, service, and transport sectors. A variety of shift systems have been implemented, and it is predicted that in the near future that night shifts will become more common in many economic fields (1). Disturbances of the human day-night rhythm due to night work can cause desynchronization of internal biological clocks that govern most functions of the body (2). The neuro- hormone melatonin plays a major role in linking light perception with chronobiology and its secretion can be influenced by exposure to light at night $(\operatorname{LAN})(3,4)$. It has been discussed that changes in melatonin levels caused by LAN might be related to the development of breast cancer $(5,6)$.

Recently, the International Agency for Research on Cancer (IARC) assessed the carcinogenicity of night

1 Equal contribution.

2 Research Institute of Occupational Medicine of the German Social Accident Insurance (BGFA), Ruhr University Bochum, Germany.

3 Department of Internal Medicine, Evangelische Kliniken Bonn gGmbH, Johanniter Krankenhaus, Bonn, Germany.

4 Dr Margarete Fischer-Bosch-Institute of Clinical Pharmacology, Stuttgart, and University Tübingen, Germany.

5 Molecular Genetics of Breast Cancer, Deutsches Krebsforschungszentrum (DKFZ), Heidelberg, Germany.

6 International Agency for Research on Cancer (IARC), Lyon, France.

Correspondence to: Professor T Brüning, Research Institute of Occupational Medicine of the German Social Accident Insurance (BGFA), Bürkle-de-la-Camp-Platz 1, 44789 Bochum, Germany. [E-mail: bruening@bgfa.de] 
work (7). On the basis of "limited evidence in humans for the carcinogenicity of shift work that involves night work" and "sufficient evidence in experimental animals for the carcinogenicity of light during the daily dark period (biological night)", an IARC working group concluded that "shift work that involves circadian disruption is probably carcinogenic to humans" (group 2A). The assessment of human data was based on results from eight epidemiological studies (8-15). Among these, two recently published studies reported no increased breast cancer risk $(14,15)$. Two large cohort studies, the nurses' health studies I and II, observed that the risk increased with increasing numbers of night shifts $(9,10)$. Shortcomings in study design and control of potential confounders were limitations of some of the aforementioned studies, as well as a crude assessment of shift characteristics and night work (16). Here we present the risk estimates of night work for breast cancer in German women from the GENICA (Gene ENvironment Interaction and breast CAncer) study.

\section{Methods}

\section{Study population and breast cancer risk factors}

GENICA was a population-based case-control study conducted among women from the Greater Region of Bonn, Germany, as previously described (17). In brief, 1143 incident breast cancer cases and 1155 population controls were enrolled between 2000 and 2004 with response rates of $88 \%$ and $67 \%$, respectively. Cases were enrolled from the major hospitals of the region. Controls were ascertained as a random sample from the population registries of the study region and frequencymatched to cases by age in 5 -year classes. Inclusion criteria comprised age $\leq 80$ years and Caucasian ethnicity. Incident cases were women with histopathologically confirmed breast cancer diagnosed within six months before enrolment. Data on known and suspected risk factors, including a detailed occupational history, were obtained by in-person interviews (hereafter referred to as the "core interview"). All participants gave written informed consent. The ethics committee of the University of Bonn approved the GENICA study.

In order to assess more detailed information on hormone therapy (18-20), subsequent telephone interviews were performed for 857 GENICA cases and 892 controls concerning their use of hormone prescriptions between 2004 and 2007. In addition, information on shiftwork status was sought (hereafter referred to as the "shift-status interview"). Of the 247 women reporting shift work, 223 (104 cases and 119 controls) could be reached for another telephone interview to collect detailed information on shift work for each occupational period (hereafter referred to as the "shift interview"). Comprehensive plausibility checks were applied to assess night work and lifetime exposure to night shifts. Night work was defined as working the fulltime period between $24.00-05.00$ hours according to the International Labor Organization (ILO) convention on night work (21). An almost equal number of 56 cases and 57 controls had ever worked in night shift for $\geq 1$ year. Shift work and other information were truncated at the date of the core interview.

\section{Statistical analysis}

The GENICA study investigated the association of night work with breast cancer using logistic regression models conditional on age (20-44, 45-49, 50-54, 55-59, 60-64, $65-69, \geq 70$ years) among 857 breast cancer cases and 892 controls with shift-status information. We calculated risk estimates as odds ratios (OR) with 95\% confidence intervals (95\% CI) using PHREG procedure in SAS software, version 9.2 (SAS Institute, Cary, NC, USA).

For model building, night work was forced into the statistical model. The set of potential confounders comprised menopausal status (pre- or postmenopausal), education, breast cancer in mother or sister, parity (nulliparous, $1-2, \geq 3$ children), age at first birth (nulliparous, $<25,25-29, \geq 30$ years), duration of oral contraceptive and hormone therapy use (never, $>0-9, \geq 10$ years), body-mass index $(<22.5,22.5-<25,25-<30$, and $\geq 30 \mathrm{~kg} / \mathrm{m} 2)$, smoking (current, former, never), number of mammograms until two years before interview, and lifetime breastfeeding in months. Women were considered pre-menopausal if they reported bleedings in the year of interview and no bilateral oophorectomy. They were categorized as "low educated" if they had no occupational qualification and $\leq 8$ years at school and "highly educated" if they had a university degree; otherwise education level was classified as "medium". Each variable was added one at a time in order to assess whether it would modify the association between night work and breast cancer. None of the potential confounders changed the risk estimate of night or shift work by more than $10 \%$. In the final model, a variable was considered a potential confounder if the respective risk estimate reached a significance level of $15 \%$. The final models included family history of breast cancer, hormone therapy use, and number of mammograms.

The reference group was defined as women employed in day work only. Never-employed women were classified as a separate group. We categorized the self-assessed employment status as "employees" (white-collar occupations), "workers" (usually blue-collar occupations), and "others" (comprising self-employed women, family workers, and employed women not classified elsewhere). We estimated risks for: (i) having ever done night work, (ii) the duration of night work, (iii) the cumulative 
number of night shifts with and without the condition of $>3$ night shifts per month using the corresponding third quartile among controls as a cut-off point (807 and 1056, respectively), (iv) age at first incidence of night work, and (v) time since last night work. Tests for linear trends were performed for quantitative exposure variables.

To account for a possible selection bias during the subsequent interviews, we applied a resampling procedure with 200 runs for both controls and cases according to the distribution of education in the core interview using Proc Surveyselect in SAS (SAS Institute, Cary, NC, USA). By means of bootstrapping, we calculated adjusted estimates of OR and $95 \% \mathrm{CI}$ for night work risk estimates.

\section{Results}

Of the original 2298 GENICA participants, 1749 women were interviewed on their use of hormone prescriptions; among these women, in a subsequent interview, shiftstatus information was documented in 857 (74.2\%) cases and $892(78.0 \%)$ controls. We observed a lower proportion of low-educated controls in the shift-status assessment compared to the core interview (12.1\% versus $14.7 \%$, data not shown). Table 1 presents the distribution of breast cancer risk factors in cases and controls and age-adjusted OR. The GENICA study population is characterized by low parity and common use of hormone therapy. Long-term use of hormone therapy and familial breast cancer were confirmed as risk factors for breast cancer.

About $13 \%$ of all women had ever been employed in shift work. Almost an equal amount of 56 cases $(6.5 \%)$ and 57 controls $(6.4 \%)$ performed night work for $\geq 1$ year. Among controls working in night shifts, $63.0 \%$ worked in healthcare. Table 2 depicts the distribution of potential risk factors for breast cancer by employment and shift status among controls. Female night workers were younger [median age 54 years, interquartile range (IQR) 42-62 years] especially when compared to women who had never been employed (median age 68 years, IQR 63-74 years). In comparison to the reference group of daytime workers, night-shift workers were more frequently nulliparous $(28.6 \%$ versus $17.8 \%)$, low educated ( $12.3 \%$ versus $9.2 \%$ ), and fewer had ever used hormone therapy $(35.7 \%$ versus $51.9 \%)$. The group of women who had never been employed differed in the distribution of reproductive and lifestyle factors. Only $36.7 \%$ had ever used oral contraceptives and $6.7 \%$ were nulliparous.

Table 3 presents OR estimates for employment and shift work status with and without adjustments for potential confounders and for a potential selection bias due to losses in response. Compared to women
Table 1. Potential breast cancer risk factors in GENICA women. [Numbers may differ due to missing values; $\mathrm{OR}=$ odds ratio, 95\% $\mathrm{Cl}=95 \%$ confidence interval]

\begin{tabular}{llllll}
\hline Factor & $\begin{array}{c}\text { Cases } \\
(\mathrm{N}=857)\end{array}$ & & $\begin{array}{c}\text { Controls } \\
(\mathrm{N}=892)\end{array}$ & $\mathrm{OR}^{\mathrm{a}} \quad 95 \% \mathrm{Cl}$ \\
\cline { 2 - 3 } & $\mathrm{N} \%$ & $\mathrm{~N} \quad \%$ & \\
\hline
\end{tabular}

\begin{tabular}{|c|c|c|c|c|c|c|}
\hline \multicolumn{7}{|l|}{ Age (years) } \\
\hline$\leq 49$ & 199 & 23.2 & 195 & 21.9 & . & .. \\
\hline $50-59$ & 268 & 31.3 & 276 & 30.9 & . & .. \\
\hline $60-69$ & 288 & 33.6 & 304 & 34.1 & . & .. \\
\hline $70-80$ & 102 & 11.9 & 117 & 13.1 & . & .. \\
\hline \multicolumn{7}{|c|}{ Menopausal status } \\
\hline Pre & 218 & 25.8 & 207 & 23.5 & 1 & .. \\
\hline Post & 627 & 74.2 & 673 & 76.5 & 0.90 & $0.64-1.25$ \\
\hline \multicolumn{7}{|l|}{ Education ${ }^{\mathrm{b}}$} \\
\hline High & 116 & 13.5 & 142 & 15.9 & 1 & .. \\
\hline Medium & 634 & 74.0 & 642 & 72.0 & 1.23 & $0.94-1.61$ \\
\hline Low & 107 & 12.5 & 108 & 12.1 & 1.28 & $0.88-1.86$ \\
\hline \multicolumn{7}{|l|}{ Parity } \\
\hline Nulliparous & 147 & 17.2 & 157 & 17.6 & 1 & \\
\hline $1-2$ children & 527 & 61.5 & 538 & 60.4 & 1.05 & $0.81-1.35$ \\
\hline$\geq 3$ children & 183 & 21.4 & 196 & 22.0 & 1.02 & $0.75-1.38$ \\
\hline
\end{tabular}

Age at first birth (years)

$\begin{array}{lrrrrrr}\text { Nulliparous } & 147 & 17.2 & 157 & 17.6 & 1 & . . \\ <25 & 341 & 39.8 & 360 & 40.4 & 1.01 & 0.77-1.33 \\ 25-29 & 241 & 28.2 & 253 & 28.4 & 1.03 & 0.77-1.37 \\ \geq 30 & 127 & 14.8 & 121 & 13.6 & 1.14 & 0.81-1.59\end{array}$

Oral contraceptives (years)

$\begin{array}{lrrrrrr}\text { Never } & 274 & 32.1 & 291 & 32.7 & 1 & . . \\ >0-9 & 283 & 33.1 & 280 & 31.5 & 1.02 & 0.79-1.32 \\ \geq 10 & 298 & 34.9 & 319 & 35.8 & 0.94 & 0.73-1.22\end{array}$

Hormone therapy (years)

$\begin{array}{lrrrrrr}\text { Never } & 415 & 48.7 & 445 & 50.0 & 1 & . . \\ >0-9 & 203 & 23.8 & 260 & 29.2 & 0.86 & 0.67-1.10 \\ \geq 10 & 235 & 27.6 & 185 & 20.8 & 1.53 & 1.16-2.00\end{array}$

Cigarette smoking (pack-years)

$\begin{array}{lrrrrrr}0 & 483 & 60.4 & 487 & 58.6 & 1 & . . \\ >0-<15 & 155 & 19.4 & 171 & 20.6 & 0.89 & 0.69-1.16 \\ \geq 15 & 162 & 20.3 & 173 & 20.8 & 0.92 & 0.72-1.19 \\ \begin{array}{l}\text { Body-mass } \\ \quad \text { index }\left(\mathrm{kg} / \mathrm{m}^{2}\right)\end{array} & & & & \\ <22.5 & 266 & 31.0 & 274 & 30.8 & 0.95 & 0.74-1.23 \\ 22.5-<25 & 218 & 25.4 & 216 & 24.2 & 1 & . . \\ 25-<30 & 246 & 28.7 & 269 & 30.2 & 0.91 & 0.71-1.18 \\ \geq 30 & 127 & 14.8 & 132 & 14.8 & 0.96 & 0.71-1.31\end{array}$

Breast cancer in mother or sisters

$\begin{array}{lrrrrrr}\text { No } & 747 & 87.2 & 830 & 93.1 & 1 & . . \\ \text { Yes } & 110 & 12.8 & 62 & 7.0 & 1.98 & 1.43-2.75\end{array}$

Number of mammograms ${ }^{c}$

$\begin{array}{lllllrr}0 & 120 & 14.0 & 134 & 15.0 & 1 & . . \\ 1-9 & 551 & 64.4 & 599 & 67.2 & 1.04 & 0.78-1.39 \\ \geq 10 & 184 & 21.5 & 158 & 17.7 & 1.36 & 0.96-1.92\end{array}$

a Logistic regression conditional on age in 5 -year groups.

${ }^{\mathrm{b}}$ Low education $=$ no occupational qualification and $\leq 8$ years at school; high education = university degree; medium = other than low or high.

c Lifetime number of mammograms until two years before interview. 
Table 2. Distribution of potential confounders in controls by shift work status. [Numbers may differ due to missing values.]

\begin{tabular}{|c|c|c|c|c|c|c|c|c|}
\hline \multirow[t]{2}{*}{ Factors } & \multicolumn{2}{|c|}{$\begin{array}{l}\text { Ever employed, } \\
\text { never shift work } \\
(\mathrm{N}=740)^{\mathrm{a}}\end{array}$} & \multicolumn{2}{|c|}{$\begin{array}{c}\text { Ever } \\
\text { shift work } \\
(\mathrm{N}=121)^{\mathrm{b}}\end{array}$} & \multicolumn{2}{|c|}{$\begin{array}{c}\text { Ever night } \\
\text { shift work } \\
(\mathrm{N}=57)^{\mathrm{c}}\end{array}$} & \multicolumn{2}{|c|}{$\begin{array}{l}\text { Never } \\
\text { employed } \\
(N=30)^{d}\end{array}$} \\
\hline & N & $\%$ & N & $\%$ & $\mathrm{~N}$ & $\%$ & N & $\%$ \\
\hline \multicolumn{9}{|c|}{ Menopausal status } \\
\hline Pre & 168 & 23.0 & 38 & 32.5 & 20 & 36.4 & 0 & 0 \\
\hline Post & 564 & 77.1 & 79 & 67.5 & 35 & 63.6 & 30 & 100 \\
\hline \multicolumn{9}{|l|}{ Parity } \\
\hline Nulliparous & 132 & 17.8 & 23 & 19.2 & 16 & 28.6 & 2 & 6.7 \\
\hline 1-2 children & 450 & 60.8 & 73 & 60.8 & 28 & 50.0 & 14 & 46.7 \\
\hline$\geq 3$ children & 158 & 21.4 & 24 & 20.0 & 12 & 21.4 & 14 & 46.7 \\
\hline \multicolumn{9}{|l|}{ Education ${ }^{e}$} \\
\hline High & 130 & 17.6 & 8 & 6.6 & 6 & 10.5 & 4 & 13.3 \\
\hline Medium & 542 & 73.2 & 89 & 73.6 & 44 & 77.2 & 11 & 36.7 \\
\hline Low & 68 & 9.2 & 24 & 19.8 & 7 & 12.3 & 15 & 50.0 \\
\hline \multicolumn{9}{|l|}{ Age at first birth } \\
\hline Nulliparous & 132 & 17.8 & 23 & 19.7 & 16 & 26.6 & 2 & 6.7 \\
\hline$<25$ years & 285 & 38.5 & 57 & 47.5 & 19 & 33.9 & 17 & 56.7 \\
\hline $25-29$ & 217 & 29.3 & 28 & 23.3 & 13 & 23.2 & 8 & 26.7 \\
\hline$\geq 30$ years & 106 & 14.3 & 12 & 10.0 & 8 & 14.3 & 3 & 10.0 \\
\hline \multicolumn{9}{|c|}{ Breast cancer in mother or sisters } \\
\hline No & 688 & 93.0 & 114 & 94.2 & 53 & 93.0 & 27 & 90.0 \\
\hline Yes & 52 & 7.0 & 7 & 5.8 & 4 & 7.0 & 3 & 10.0 \\
\hline \multicolumn{9}{|c|}{ Oral contraceptive use } \\
\hline Never & 238 & 32.2 & 34 & 28.3 & 17 & 30.4 & 19 & 63.3 \\
\hline$>0-9$ years & 228 & 30.9 & 47 & 39.2 & 9 & 33.9 & 5 & 16.7 \\
\hline$\geq 10$ years & 273 & 36.9 & 39 & 32.5 & 20 & 35.7 & 6 & 20.0 \\
\hline \multicolumn{9}{|c|}{ Hormone therapy } \\
\hline Never & 356 & 48.1 & 71 & 59.7 & 36 & 64.3 & 17 & 56.7 \\
\hline$>0-9$ years & 226 & 30. & 26 & 21.9 & 12 & 21. & 8 & 26.7 \\
\hline$\geq 10$ years & & 21.4 & 22 & & 8 & 14.3 & 5 & 16.7 \\
\hline \multicolumn{9}{|l|}{ Smoking } \\
\hline Never & 405 & 54.7 & 59 & 48.8 & 29 & 50.9 & 23 & 76.7 \\
\hline Former & 166 & 22.4 & 29 & 24.0 & 16 & 28.1 & 4 & 13.3 \\
\hline Current & 169 & 22.8 & 33 & 27.3 & 12 & 21.1 & 3 & 10.0 \\
\hline \multicolumn{9}{|c|}{ Body-mass index $\left(\mathrm{kg} / \mathrm{m}^{2}\right)$} \\
\hline$<22.5$ & 237 & 32.0 & 28 & 23.3 & 15 & 26.8 & 9 & 30.0 \\
\hline $22.5-<25$ & 181 & 24.5 & 27 & 22.5 & 17 & 30.4 & 7 & 23.3 \\
\hline $25-<30$ & 219 & 29.6 & 41 & 34.2 & 16 & 28.6 & 9 & 30.0 \\
\hline$\geq 30$ & 103 & 13.9 & 24 & 20.0 & 8 & 14.3 & 5 & 16.7 \\
\hline \multicolumn{9}{|c|}{ Employment status } \\
\hline Worker & 50 & 6.8 & 22 & 18.2 & 5 & 8.8 & - & \\
\hline Employee & 609 & 82.3 & 91 & 75.2 & 47 & 86.0 & - & \\
\hline Others ${ }^{\dagger}$ & 81 & 11.0 & 8 & 6.6 & 2 & 5.3 & - & \\
\hline \multicolumn{9}{|c|}{ Number of mammograms ${ }^{g}$} \\
\hline None & 100 & 13.5 & 30 & 24.8 & 15 & 26.8 & 4 & 13.3 \\
\hline $1-9$ & 502 & 67.8 & 72 & 59.5 & 31 & 55.4 & 24 & 80.0 \\
\hline$\geq 10$ & 138 & 18.7 & 18 & 14.9 & 10 & 17.9 & 2 & 6.7 \\
\hline
\end{tabular}

${ }^{\text {a }}$ Median age 58 years (interquartile range $51-65$ ).

b Medium age 56 years (interquartile range 45-62). For one woman, information on shift status was missing.

${ }^{c}$ Medium age 54 years (interquartile range 42-62).

${ }^{\mathrm{a}}$ Medium age 68 years (interquartile range 63-74).

${ }^{\mathrm{e}}$ Low education $=$ no occupational qualification and $\leq 8$ years at school; high education = university degree; medium $=$ other than low or high

${ }^{\dagger}$ Other employment comprised self-employed women, women helping the partner in his business, and women in educational programs.

${ }^{g}$ Lifetime number of mammograms until two years before interview. employed in day shifts only, the variables of having ever done shift or night work were not associated with breast cancer risk $\left(\mathrm{OR}_{\text {bootstrap }} 0.96,95 \% \mathrm{CI} 0.67-1.38\right.$ and $\mathrm{OR}_{\text {bootstrap }} 0.91,95 \%$ CI $0.55-1.49$, respectively). Neveremployed women showed an elevated risk estimate for breast cancer compared to employed women, but this was, however, not statistically significant $\left(\mathrm{OR}_{\text {bootstrap }}\right.$ $1.61,95 \%$ CI $0.86-3.02$ ).

We were able to assess detailed information on shift work in $90 \%$ of the validated shift workers. Results for night shift workers are presented in table 4. Cases had worked more night shifts during their lifetime than controls (median 791, IQR 360-1440 versus 318, IQR $180-807$ ). Working $\geq 806$ night shifts was associated with an increased risk of breast cancer, which however was not statistically significant $\left(\mathrm{OR}_{\text {bootstrap }} 1.73,95 \%\right.$ CI $0.71-4.22$, based on 13 controls and 23 cases). Five controls and 12 cases reported having done night work for $\geq 20$ years, which resulted in an $\mathrm{OR}_{\text {bootstrap }}$ of 2.48 (95\% CI 0.62-9.99). The risk estimate was 0.61 (95\% CI $0.27-1.41$ ) after $\geq 20$ years since last night work. We found no significant trend for a cumulative number of night shifts $(\mathrm{P}=0.14)$, years in night shift $(\mathrm{P}=0.16)$, and time since last night shift $(\mathrm{P}=0.09)$.

Further analyses were performed and restricted to postmenopausal women and additionally adjusted for body mass index. In general, these risk estimates were similar to the results presented here and are given in two supplementary tables (see appendix).

\section{Discussion}

In our study, having ever done night shift work was not associated with an increased breast cancer risk. Cases experienced on average about 800 night shifts in comparison to 300 among controls. Long-term night work was found to be associated with a modestly increased breast cancer risk although this was statistically not significant. The risk estimates turned out to be robust with regard to adjustment for potential confounders and a potential selection bias. Similarly, modestly elevated breast cancer risks were observed only after long-term night work of $\geq 20$ years in the nurses' health cohort studies $(9,10)$.

About $15-20 \%$ of the European and US workforce is engaged in a broad variety of shift systems (7). In Germany, approximately $10 \%$ of working women are currently employed in night work, mostly in the health and service sector, and the trend is increasing (22). In West Germany, women were prohibited from working at night in the industrial sector until the law was amended in 1992. Therefore, only $11 \%$ of female controls working the night shift were blue-collar workers; $7 \%$ of the controls had worked in night shifts for $\geq 1$ year. The even lower 
Table 3. Association between employment status and breast cancer in the GENICA study. [Numbers may differ because of missing values and refer to numbers of subjects in the adjusted model without bootstrapping. OR = odds ratio, $95 \% \mathrm{Cl}=95 \%$ confidence interval]

\begin{tabular}{|c|c|c|c|c|c|c|c|c|c|c|}
\hline \multirow[t]{2}{*}{ Factor } & \multicolumn{2}{|c|}{ Cases $(\mathrm{N}=857)$} & \multicolumn{2}{|c|}{ Controls (N=892) } & \multirow[t]{2}{*}{$\mathrm{OR}^{\mathrm{a}}$} & \multirow[t]{2}{*}{$95 \% \mathrm{Cl}$} & \multirow{2}{*}{$\begin{array}{c}\text { Adjusted } \\
\mathrm{OR}^{\mathrm{b}}\end{array}$} & \multirow{2}{*}{$95 \% \mathrm{Cl}$} & \multirow{2}{*}{$\begin{array}{c}\text { Bootstrap } \\
\text { OR }{ }^{c}\end{array}$} & \multirow{2}{*}{ p $95 \% \mathrm{Cl}$} \\
\hline & N & $\%$ & $\mathrm{~N}$ & $\%$ & & & & & & \\
\hline \multicolumn{11}{|l|}{ Current or last occupation } \\
\hline Employee & 647 & 76.1 & 699 & 78.6 & 1.00 & & 1.00 & & 1.00 & \\
\hline Worker & 69 & 8.1 & 71 & 8.0 & 1.06 & $0.75-1.50$ & 1.12 & $0.78-1.59$ & 1.09 & $0.70-1.70$ \\
\hline Others ${ }^{d}$ & 94 & 11.1 & 89 & 10.0 & 1.17 & $0.86-1.60$ & 1.23 & $0.89-1.68$ & 1.24 & $0.83-1.85$ \\
\hline Never employed & 40 & 4.7 & 30 & 3.4 & 1.55 & $0.94-2.55$ & 1.60 & $0.97-2.66$ & 1.68 & $0.89-3.17$ \\
\hline \multicolumn{11}{|l|}{ Shift work } \\
\hline Employed, but never in shift work & 698 & 82.1 & 740 & 83.2 & 1.00 & . & 1.00 & . & 1.00 & . \\
\hline Ever in shift work & 112 & 13.2 & 119 & 13.4 & 0.97 & $0.74-1.29$ & 0.98 & $0.74-1.29$ & 0.96 & $0.67-1.38$ \\
\hline Never employed & 40 & 4.7 & 30 & 3.4 & 1.51 & $0.92-2.47$ & 1.54 & $0.93-2.54$ & 1.61 & $0.86-3.02$ \\
\hline \multicolumn{11}{|l|}{ Night shift work } \\
\hline Employed, but never in shift work & 698 & 92.7 & 740 & 92.7 & 1.00 & . & 1.00 & . & 1.00 & \\
\hline Ever in night shift work & 55 & 7.3 & 56 & 7.0 & 1.02 & $0.69-1.50$ & 1.01 & $0.68-1.50$ & 0.91 & $0.55-1.49$ \\
\hline
\end{tabular}

${ }^{a}$ Logistic regression conditional on age in 5-year groups.

b Logistic regression conditional on age in 5-year groups, adjusted for family history of breast cancer, hormone replacement use, and number of mammograms.

c Corrected for a potential selection bias using a resampling and bootstrapping procedure with logistic regression models conditional on age in 5-year groups, adjusted for family history of breast cancer, hormone replacement use, and number of mammograms.

d Other employment included self-employed women, women helping the partner in business, and women in educational programs.

Table 4. Quantitative assessment of night shift and its association with breast cancer in GENICA women with $>1$ year night shift work. [Numbers may differ because of missing values and refer to numbers of subjects in the adjusted model without bootstrapping. OR $=0 \mathrm{dds}$ ratio, $95 \% \mathrm{Cl}=95 \%$ confidence interval]

\begin{tabular}{|c|c|c|c|c|c|c|c|c|c|c|}
\hline \multirow[t]{2}{*}{ Factor } & \multicolumn{2}{|c|}{$\begin{array}{l}\text { Cases } \\
(\mathrm{N}=746)\end{array}$} & \multicolumn{2}{|c|}{$\begin{array}{l}\text { Controls } \\
(\mathrm{N}=793)\end{array}$} & \multirow[t]{2}{*}{$O \mathrm{R}^{\mathrm{a}}$} & \multirow[t]{2}{*}{$95 \% \mathrm{Cl}$} & \multirow[t]{2}{*}{$\begin{array}{c}\text { Adjusted } \\
\mathrm{OR}^{\mathrm{b}}\end{array}$} & \multirow[t]{2}{*}{$95 \% \mathrm{Cl}$} & \multirow[t]{2}{*}{$\begin{array}{c}\text { Bootstrap } \\
\text { OR }^{c}\end{array}$} & \multirow[t]{2}{*}{ p $95 \% \mathrm{Cl}$} \\
\hline & N & $\%$ & $\mathrm{~N}$ & $\%$ & & & & & & \\
\hline \multicolumn{11}{|c|}{ Cumulative number of lifetime night shifts } \\
\hline Employed, but never in shift work & 698 & 93.6 & 740 & 93.3 & 1.00 & . & 1.00 & . & 1.00 & . \\
\hline$<807$ night shifts & 25 & 3.4 & 40 & 5.0 & 0.66 & $0.40-1.10$ & 0.66 & $0.40-1.11$ & 0.65 & $0.34-1.26$ \\
\hline$\geq 807$ night shift & 23 & 3.1 & 13 & 1.6 & 1.81 & $0.91-3.60$ & 1.78 & $0.89-3.58$ & 1.73 & $0.71-4.22$ \\
\hline \multicolumn{11}{|c|}{ Cumulative number of lifetime night shifts for shift systems with $>3$ nights per month } \\
\hline Employed, but never in shift work & 698 & 93.9 & 740 & 94.3 & 1.00 & . & 1.00 & . & 1.00 & · \\
\hline$<1056$ night shifts & 25 & 3.4 & 33 & 4.2 & 0.79 & $0.47-1.34$ & 0.80 & $0.47-1.36$ & 0.79 & $0.40-1.57$ \\
\hline$\geq 1056$ night shifts & 20 & 2.7 & 12 & 1.5 & 1.69 & $0.82-3.48$ & 1.66 & $0.80-3.46$ & 1.61 & $0.63-4.10$ \\
\hline \multicolumn{11}{|l|}{ Duration of night shift work } \\
\hline Employed, but never in shift work & 698 & 93.6 & 740 & 93.3 & 1.00 & . & 1.00 & . & 1.00 & . \\
\hline$>0-4$ years & 15 & 2.0 & 25 & 3.2 & 0.68 & $0.36-1.29$ & 0.64 & $0.34-1.24$ & 0.65 & $0.28-1.48$ \\
\hline $5-9$ years & 11 & 1.5 & 12 & 1.5 & 0.85 & $0.38-1.90$ & 0.93 & $0.41-2.15$ & 0.93 & $0.31-2.82$ \\
\hline $10-19$ years & 10 & 1.3 & 11 & 1.4 & 0.94 & $0.39-2.23$ & 0.91 & $0.38-2.18$ & 0.83 & $0.27-2.60$ \\
\hline$\geq 20$ years & 12 & 1.6 & 5 & 0.6 & 2.47 & $0.87-7.05$ & 2.49 & $0.87-7.18$ & 2.48 & $0.62-9.99$ \\
\hline \multicolumn{11}{|l|}{ Age at time of first night shift work } \\
\hline Employed, but never in shift work & 698 & 93.6 & 740 & 93.3 & 1.00 & . & 1.00 & . & 1.00 & . \\
\hline$<20$ years & 14 & 1.9 & 28 & 3.5 & 0.56 & $0.30-1.06$ & 0.53 & $0.28-1.03$ & 0.52 & $0.23-1.20$ \\
\hline $20-29$ years & 25 & 3.4 & 17 & 2.1 & 1.52 & $0.81-2.84$ & 1.51 & $0.80-2.83$ & 1.50 & $0.67-3.40$ \\
\hline $30-39$ years & 6 & 0.8 & 5 & 0.6 & 1.03 & $0.33-3.22$ & 1.25 & $0.38-4.15$ & 1.26 & $0.23-6.04$ \\
\hline$\geq 40$ years & 3 & 0.4 & 3 & 0.4 & 1.04 & $0.21-5.18$ & 0.98 & $0.19-5.09$ & 1.02 & $0.11-9.09$ \\
\hline \multicolumn{11}{|l|}{ Years since last night shift } \\
\hline Employed, but never in shift work & 698 & 93.6 & 740 & 93.3 & 1.00 & . & 1.00 & . & 1.00 & . \\
\hline Current night work & 14 & 1.9 & 13 & 1.6 & 1.09 & $0.50-2.35$ & 1.10 & $0.51-2.38$ & 1.07 & $0.39-2.88$ \\
\hline$>1-9$ years & 6 & 0.8 & 5 & 0.6 & 1.22 & $0.37-4.00$ & 1.04 & $0.31-3.53$ & 1.20 & $0.20-5.63$ \\
\hline $10-19$ years & 13 & 1.7 & 8 & 1.0 & 1.48 & $0.63-3.50$ & 1.69 & $0.69-4.14$ & 1.67 & $0.52-5.38$ \\
\hline$\geq 20$ years & 15 & 2.0 & 27 & 3.4 & 0.64 & $0.34-1.20$ & 0.62 & $0.33-1.19$ & 0.61 & $0.27-1.41$ \\
\hline
\end{tabular}

a Logistic regression conditional on age in 5-year groups.

b Logistic regression conditional on age, adjusted for family history of breast cancer, hormone replacement use, and number of mammograms.

c Corrected for a potential selection bias using a resampling and bootstrapping procedure with logistic regression models conditional on age in 5-year groups,

adjusted for family history of breast cancer, hormone replacement use, and number of mammograms. 
prevalence of long-term night work limited the precision of our results on the night work risk for breast cancer.

The multitude of shift systems raised the question of an appropriate assessment of shift characteristics. The IARC working group concluded that the collection of shift work information in several studies was rather crude (7). The ILO has defined a night shift as work which is performed for $\geq 7$ hours between 12.00 05.00 hours. (21). As our study focused on the risk of occupational shift work and breast cancer, the few women who reported healthcare duties in their families were not classified as night workers. The 12.00-05.00 time period includes the physiological peak of melatonin biosynthesis around 01.00-02.00 hours. (23). Artificial light at night can modify the diurnal melatonin production. It has been proposed that suppressed melatonin production may lead to an increased cancer risk, but further research is needed to fully establish the mechanistic pathways leading to circadian disruption and cancer (24-28). However, cancer as a systemic disease or the treatment thereof can interfere with biomarker levels, making case-control studies less suitable for the determination of melatonin and other biomarkers.

The limitations of our study included a low prevalence of night work, especially long-term night work, and the retrospective assessment of shift work in subsequent interviews. Primarily, GENICA aimed to investigate gene-environment interactions (29-31) and contributes to the International Breast Cancer Association Consortium $(32,33)$. When the first epidemiological results for night work as a potential risk factor for breast cancer were emerging, we added questions on shift work to our study. At that time, women were not aware that night work might pose a risk. However, participants in the consecutive interviews tended to be better educated. Therefore, we applied resampling according to the distribution of education in the core interview and bootstrapping to adjust the risk estimates for night work. The risk estimates were relatively robust with respect to this potential selection bias.

Women in night work can differ with regard to reproductive and hormonal factors that are established risk factors for breast cancer and potential confounding was raised as a concern (16). In our study, women working in night shifts were more frequently nulliparous, and hormone therapy use was less common. However, our results were very similar when comparing statistical models including only age with models additionally adjusting for hormonal and other factors, or full models, and do not provide evidence for potential confounding. Depending on the underlying causal model, other variables (eg, LAN from non-occupational sources, sleep deprivation and ensuing immune suppression) may also be considered as potential confounders or intermediate variables. To explore this further, future epidemiological studies on circadian disruption and cancer should try to capture these domains of exposure. Finally, the effect of shift work on breast cancer may be also modified by individual susceptibility to different working schedules, which can result from differential adaptability to night shifts (34).

The lifetime numbers of night shifts or the years employed in night work are crude surrogate measures and do not fully represent the various characteristics of complex shift systems. For example, the direction of the shift rotation and the timing of recovery days can influence phase shifts of melatonin concentrations (35). Furthermore, there is not yet a consensus on how best to assess circadian disruption and its potential mechanistic links to cancer (36).

In conclusion, our results are in line with the IARC classification that long-term night work in women is probably associated with breast cancer and warrants further research (37). A major challenge is the quantitative assessment of night work and qualitative assessment of various shift systems. Shift systems are an integral part of the organization of work and strategies are needed to minimize possible health hazards of night work.

\section{Acknowledgements}

This work was supported by the German Federal Ministry of Education and Research (BMBF) grants 01KW9975/5, 01KW9976/8, 01KW9977/0, 01KW0114, and 01KH0411, the Research Institute of Occupational Medicine of the German Social Accident Insurance (BGFA), the Robert Bosch Foundation of Medical Research, the Evangelische Kliniken (Evangelical Clinic) Bonn GmbH, and the Deutsches Krebsforschungszentrum (German Cancer Research Center).

\section{References}

1. Akerstedt T, Kecklund G. The future of work hours - the European view. Ind Health. 2005;43:80-4.

2. Siepka SM, Yoo SH, Park J, Lee C, Takahashi JS. Genetics and neurobiology of circadian clocks in mammals. Cold Spring Harb Symp Quant Biol. 2007;72:251-9.

3. Stevens RG. Electric power use and breast cancer: a hypothesis. Am J Epidemiol. 1987;125:556-61.

4. Arendt J. Melatonin: characteristics, concerns, and prospects. J Biol Rhythms. 2005;20:291-303.

5. Brzezinski A. Melatonin in humans. N Engl J Med. 1997;336:186-95.

6. Stevens RG. Light-at-night, circadian disruption and breast cancer: assessment of existing evidence. Int $\mathrm{J}$ Epidemiol. 2009;38(4):963-70. 
7. Straif K, Bouvard V, Altieri A, Benbrahim-Tallaa L, Cogliano V. Carcinogenicity of shift-work, painting, and fire-fighting. Lancet Oncol. 2007;8:1065-6.

8. Hansen J. Light at night, shiftwork, and breast cancer risk. J Natl Cancer Inst. 2001;93:1513-5.

9. Schernhammer ES, Laden F, Speizer FE, Willett WC, Hunter DJ, Kawachi I, et al. Rotating night shifts and risk of breast cancer in women participating in the nurses' health study. J Natl Cancer Inst. 2001;93:1563-8.

10. Schernhammer ES, Kroenke CH, Laden F, Hankinson SE. Night work and risk of breast cancer. Epidemiology. 2006;17:108-11.

11. O'Leary ES, Schoenfeld ER, Stevens RG, Kabat GC, Henderson K, Grimson R, et al. Shift work, light at night, and breast cancer on Long Island, New York. Am J Epidemiol. 2006;164:358-66.

12. Lie JA, Roessink J, Kjaerheim K. Breast cancer and night work among Norwegian nurses. Cancer Causes Control. 2006;17:39-44.

13. Tynes T, Hannevik M, Andersen A, Vistnes AI, Haldorsen T. Incidence of breast cancer in Norwegian female radio and telegraph operators. Cancer Causes Control. 1996;7:197-204.

14. Davis S, Mirick DK. Circadian disruption, shift work and the risk of cancer: a summary of the evidence and studies in Seattle. Cancer Causes Control. 2006;17:539-45.

15. Schwartzbaum J, Ahlbom A, Feychting M. Cohort study of cancer risk among male and female shift workers. Scand J Work Environ Health 2007;33:336-43.

16. Kolstad HA. Nightshift work and risk of breast cancer and other cancers - a critical review of the epidemiologic evidence [review]. Scand J Work Environ Health. 2008;34(1):5-22.

17. Pesch B, Ko Y, Brauch H, Hamann U, Harth V, Rabstein S et al. Factors modifying the association between hormonereplacement therapy and breast cancer risk. Eur J Epidemiol. 2005;20:699-711.

18. Schmidt ME, Steindorf K, Mutschelknauss E, Slanger T, Kropp S, Obi N, et al. Physical activity and postmenopausal breast cancer: effect modification by breast cancer subtypes and effective periods in life. Cancer Epidemiol Biomarkers Prev. 2008;17:3402-10.

19. Flesch-Janys D, Slanger T, Mutschelknauss E, Kropp S, Obi $\mathrm{N}$, Vettorazzi E, et al. Risk of different histological types of postmenopausal breast cancer by type and regimen of menopausal hormone therapy. Int J Cancer. 2008;123:933-41.

20. Kropp S, Terboven T, Hedicke J, Mutschelknauss E, Slanger $\mathrm{T}$, Braendle W, et al. Good agreement between physician and self-reported hormone therapy data in a case-control study. J Clin Epidemiol. 2007;60:1280-7.

21. International Labour Organization (ILO). C171 Night Work Convention, 1990. General Conference of the International Labour Organization in Geneva, 77th Session. Available from: www.ilo.org/ilolex/cgi-lex/convde.pl?C171.

22. Breiholz H, Duschek K, Hansch E, Nöthen M. Leben und Arbeiten in Deutschland - Ergebnisse des Mikrozensus 2004. [Living and working in Germany - results of the Mikrocensus 2004]. Wiesbaden (Germany): Statistisches Bundesamt; 2005.
23. Zhou JN, Liu RY, van Heerikhuize J, Hofman MA, Swaab DF. Alterations in the circadian rhythm of salivary melatonin begin during middle-age. J Pineal Res. 2003;34:11-6.

24. Haus E, Smolensky M. Biological clocks and shift work: circadian dysregulation and potential long-term effects. Cancer Causes Control. 2006;17:489-500.

25. Haus E. Chronobiology in the endocrine system. Adv Drug Deliv Rev. 2007;59:985-1014.

26. Stevens RG. Circadian disruption and breast cancer: from melatonin to clock genes. Epidemiology. 2005;16:254-8.

27. Viswanathan AN, Schernhammer ES. Circulating melatonin and the risk of breast and endometrial cancer in women. Cancer Lett. 2009;281:1-7.

28. Stevens RG, Blask DE, Brainard GC, Hansen J, Lockley SW, Provencio I, et al. Meeting report: the role of environmental lighting and circadian disruption in cancer and other diseases. Environ Health Perspect. 2007;115:1357-62.

29. Abraham BK, Justenhoven C, Pesch B, Harth V, Weirich G, Baisch $\mathrm{C}$, et al. Investigation of genetic variants of genes of the hemochromatosis pathway and their role in breast cancer. Cancer Epidemiol Biomarkers Prev. 2005;14:1102-7.

30. Justenhoven C, Hamann U, Pesch B, Harth V, Rabstein S, Baisch $\mathrm{C}$, et al. ERCC2 genotypes and a corresponding haplotype are linked with breast cancer risk in a German population. Cancer Epidemiol Biomarkers Prev. 2004;13:2059-64.

31. Justenhoven C, Hamann U, Pierl CB, Rabstein S, Pesch B, Harth $\mathrm{V}$, et al. One-carbon metabolism and breast cancer risk: no association of MTHFR, MTR, and TYMS polymorphisms in the GENICA study from Germany. Cancer Epidemiol Biomarkers Prev. 2005;14:3015-8.

32. Ahmed S, Thomas G, Ghoussaini M, Healey CS, Humphreys MK, Platte R, et al. Newly discovered breast cancer susceptibility loci on 3 p24 and 17q23.2. Nat Genet. 2009;41:585-90.

33. Easton DF, Pooley KA, Dunning AM, Pharoah PD, Thompson $\mathrm{D}$, Ballinger DG, et al. Genome-wide association study identifies novel breast cancer susceptibility loci. Nature. 2007;447:1087-93.

34. Sack RL, Auckley D, Auger RR, Carskadon MA, Wright KP, Jr, Vitiello MV, et al. Circadian rhythm sleep disorders: part I, basic principles, shift work and jet lag disorders: an American Academy of Sleep Medicine review. Sleep. 2007;30:1460-83.

35. Gibbs M, Hampton S, Morgan L, Arendt J. Effect of shift schedule on offshore shiftworkers' circadian rhythms and health. Guildford (United Kingdom): Health and Safety Executive; 2005. Research report 318.

36. Erren TC, Pape HG, Reiter RJ, Piekarski C. Chronodisruption and cancer. Naturwissenschaften. 2008;95:367-82.

37. Erren TC, Morfeld P, Stork J, Knauth P, von Mülmann MJA, Breitstadt R, et al. Shift work, chronodisruption and cancer? - The IARC 2007 challenge for research and prevention and 10 theses from the Cologne Colloquium 2008. Scand J Work Environ Health. 2009;35:74-9.

Received for publication: 7 September 2009 


\section{Appendix}

Table A. Association between employment status and breast cancer in postmenopausal women. [Numbers may differ because of missing values and refer to numbers of subjects in footnote $b$ model; $\mathrm{OR}=0 \mathrm{dds}$ ratio; $95 \% \mathrm{Cl}=95 \%$ confidence interval.]

\begin{tabular}{|c|c|c|c|c|c|c|c|c|c|c|}
\hline \multirow[t]{2}{*}{ Factor } & \multicolumn{2}{|c|}{ Cases $(\mathrm{N}=627)$} & \multicolumn{2}{|c|}{ Controls (N=673) } & \multirow[t]{2}{*}{$O \mathrm{R}^{\mathrm{a}}$} & \multirow[t]{2}{*}{$95 \% \mathrm{Cl}$} & \multirow{2}{*}{$\begin{array}{c}\text { Adjusted } \\
\mathrm{OR}^{\mathrm{b}}\end{array}$} & \multirow{2}{*}{$95 \% \mathrm{Cl}$} & \multirow{2}{*}{$\begin{array}{c}\text { Adjusted } \\
\mathrm{OR}^{\mathrm{c}}\end{array}$} & \multirow[t]{2}{*}{$95 \% \mathrm{Cl}$} \\
\hline & N & $\%$ & $\mathrm{~N}$ & $\%$ & & & & & & \\
\hline \multicolumn{11}{|l|}{ Current or last occupation } \\
\hline Employee & 454 & 73.1 & 512 & 76.2 & 1.00 & .. & 1.00 & .. & 1.00 & .. \\
\hline Worker & 58 & 9.3 & 64 & 9.5 & 1.02 & $0.70-1.48$ & 1.08 & $0.74-1.59$ & 1.08 & $0.74-1.59$ \\
\hline Others ${ }^{d}$ & 74 & 11.9 & 66 & 9.8 & 1.30 & $0.91-1.85$ & 1.36 & $0.95-1.95$ & 1.36 & $0.95-1.95$ \\
\hline Never employed & 35 & 5.6 & 30 & 4.5 & 1.37 & $0.82-2.29$ & 1.43 & $0.85-2.42$ & 1.43 & $0.86-2.41$ \\
\hline \multicolumn{11}{|l|}{ Shift work } \\
\hline Employed, but never in shift work & 510 & 82.1 & 564 & 83.9 & 1.00 & .. & 1.00 & .. & 1.00 & .. \\
\hline Ever in shift work & 76 & 12.3 & 78 & 11.6 & 1.06 & $0.76-1.48$ & 1.05 & $0.75-1.48$ & 1.05 & $0.74-1.49$ \\
\hline Never employed & 35 & 5.6 & 30 & 4.5 & 1.33 & $0.80-2.21$ & 1.37 & $0.81-2.30$ & 1.36 & $0.81-2.29$ \\
\hline \multicolumn{11}{|l|}{ Night shift work } \\
\hline Employed, but never in shift work & 510 & 93.8 & 564 & 94.2 & 1.00 & .. & 1.00 & .. & 1.00 & .. \\
\hline Ever in night shift work & 34 & 6.3 & 35 & 5.8 & 1.09 & $0.67-1.77$ & 1.05 & $0.64-1.73$ & 1.06 & $0.65-1.73$ \\
\hline
\end{tabular}

a Logistic regression conditional on age in 5 -year groups.

${ }^{b}$ Logistic regression conditional on age in 5-year groups, adjusted for family history of breast cancer, hormone replacement use, and number of mammograms.

c Logistic regression conditional on age in 5-year groups, adjusted for family history of breast cancer, hormone replacement use, number of mammograms, and body-mass index.

d Other employment included self-employed women, women helping the partner in business, and women in educational programs.

Table B. Quantitative assessment of night shift and its association with breast cancer in postmenopausal GENICA women with >1 year night shift work. [Numbers may differ because of missing values and refer to numbers of subjects in footnote $b$ model; OR=odds ratio; $95 \% \mathrm{Cl}=95 \%$ confidence interval.]

\begin{tabular}{|c|c|c|c|c|c|c|c|c|c|c|}
\hline \multirow[t]{2}{*}{ Factor } & \multicolumn{2}{|c|}{ Cases $(N=540)$} & \multicolumn{2}{|c|}{ Controls $(\mathrm{N}=597)$} & \multirow[t]{2}{*}{$\mathrm{OR}^{\mathrm{a}}$} & \multirow[t]{2}{*}{$95 \% \mathrm{Cl}$} & \multirow{2}{*}{$\begin{array}{c}\text { Adjusted } \\
\mathrm{OR}^{\mathrm{b}}\end{array}$} & \multirow{2}{*}{ d $95 \% \mathrm{Cl}$} & \multirow{2}{*}{$\begin{array}{c}\text { Adjusted } \\
\mathrm{OR}^{\mathrm{c}}\end{array}$} & \multirow[t]{2}{*}{$95 \% \mathrm{Cl}$} \\
\hline & $\mathrm{N}$ & $\%$ & $\mathrm{~N}$ & $\%$ & & & & & & \\
\hline \multicolumn{11}{|c|}{ Cumulative number of lifetime night shifts } \\
\hline Employed, but never in shift work & 510 & 94.4 & 564 & 94.5 & 1.00 & .. & 1.00 & .. & 1.00 & . \\
\hline$<807$ night shifts & 16 & 3.0 & 26 & 4.4 & 0.70 & $0.37-1.31$ & 0.65 & $0.34-1.23$ & 0.65 & $0.34-1.24$ \\
\hline$\geq 807$ night shifts & 14 & 2.6 & 7 & 1.2 & 2.23 & $0.89-5.56$ & 2.29 & $0.91-5.78$ & 2.28 & $0.90-5.76$ \\
\hline \multicolumn{11}{|c|}{ Cumulative number of lifetime night shifts for shift systems with >3 nights per month } \\
\hline Employed, but never in shift work & 510 & 95.0 & 564 & 95.0 & 1.00 & .. & 1.00 & .. & 1.00 & . \\
\hline$<1056$ night shifts & 16 & 3.0 & 24 & 4.0 & 0.76 & $0.40-1.43$ & 0.71 & $0.39-1.36$ & 0.72 & $0.37-1.38$ \\
\hline$\geq 1056$ night shifts & 11 & 2.0 & 6 & 1.0 & 2.01 & $0.74-5.47$ & 2.09 & $0.76-5.78$ & 2.1 & $0.76-5.81$ \\
\hline \multicolumn{11}{|l|}{ Duration of night shift work } \\
\hline Employed, but never in shift work & 510 & 88.4 & 564 & 88.7 & 1.00 & .. & 1.00 & .. & 1.00 & . \\
\hline$>0-<5$ years & 9 & 1.6 & 20 & 3.1 & 0.52 & $0.24-1.14$ & 0.46 & $0.21-1.03$ & 0.47 & $0.21-1.04$ \\
\hline $5-9$ years & 7 & 1.2 & 5 & 0.8 & 1.55 & $0.49-4.92$ & 1.54 & $0.48-4.97$ & 1.55 & $0.48-5.02$ \\
\hline $10-19$ years & 5 & 0.9 & 4 & 0.7 & 1.43 & $0.38-5.34$ & 1.45 & $0.38-5.57$ & 1.48 & $0.39-5.66$ \\
\hline$\geq 20$ years & 9 & 1.7 & 4 & 0.7 & 2.47 & $0.76-8.06$ & 2.60 & $0.89-8.57$ & 2.65 & $0.78-8.48$ \\
\hline \multicolumn{11}{|l|}{ Age at first night shift work } \\
\hline Employed, but never in shift work & 510 & 94.4 & 564 & 94.5 & 1.00 & .. & 1.00 & .. & 1.00 & . \\
\hline$<20$ years & 13 & 2.4 & 15 & 2.5 & 1.05 & $0.50-2.19$ & 0.99 & $0.47-2.11$ & 1.00 & $0.49-2.14$ \\
\hline $20-29$ years & 12 & 2.2 & 11 & 1.8 & 1.14 & $0.49-2.62$ & 1.12 & $0.48-2.59$ & 1.24 & $0.48-2.61$ \\
\hline 30-39 years & 2 & 0.4 & 4 & 0.7 & 0.55 & $0.10-3.02$ & 0.54 & $0.10-3.02$ & 0.52 & $0.90-2.94$ \\
\hline$\geq 40$ years & 3 & 0.6 & 3 & 0.5 & 1.07 & $0.22-5.34$ & 1.03 & $1.11-2.50$ & 1.05 & $0.20-5.47$ \\
\hline \multicolumn{11}{|l|}{ Years since last night shift } \\
\hline Employed, but never in shift work & 510 & 94.4 & 564 & 97.5 & 1.00 & .. & 1.00 & .. & 1.00 & . \\
\hline Current night work & 6 & 1.1 & 4 & 0.7 & 163 & $0.45-5.86$ & 1.76 & $0.48-6.31$ & 1.79 & $0.49-6.52$ \\
\hline$>1-9$ years & 3 & 0.6 & 3 & 0.5 & 1.03 & $0.21-5.10$ & 0.84 & $0.16-4.39$ & 0.82 & $0.16-4.35$ \\
\hline $10-19$ years & 7 & 1.3 & 4 & 0.7 & 1.95 & $0.56-6.74$ & 1.91 & $0.55-6.67$ & 1.90 & $0.55-6.64$ \\
\hline$\geq 20$ years & 14 & 2.6 & 22 & 3.7 & 0.74 & $0.38-1.45$ & 0.71 & $0.36-1.40$ & 0.71 & $0.36-1.41$ \\
\hline
\end{tabular}

a Logistic regression conditional on age in 5-year groups.

b Logistic regression conditional on age in 5-year groups, adjusted for family history of breast cancer, hormone replacement use, and number of mammograms.

c Logistic regression conditional on age in 5-year groups, adjusted for family history of breast cancer, hormone replacement use, number of mammograms, and body-mass index. 